\title{
KONSEP DAN KONTEKSTUALISASI KEPEMIMPINAN DALAM HADIS
}

\author{
Oleh: Wahyu Saepudin \\ Islam Negeri Sunan Kalijaga Yogyakarta \\ Email: yoodeen1419@gmail.com,
}

\begin{abstract}
Abstrak
Kepemimpinan merupakan suatu entitas yang penting bagi peradaban manusia. Adanya suatu komunitas yang eksis, memerlukan suatu bentuk kepemimpinan yang akan mengarahkan komunitas tersebut kepada tujuan dan visi serta misi yang hendak dicapai. Politik, sebagai suatu panglima yang mengarahkan komunitas merupakan manifestasi konkret dari adanya kepemimpinan. Islam sebagai agama yang menjadikan teks al-Qur'an dan Hadis beserta ilmu turunannya sebagai pedoman, tentunya memiliki konsepsi ideal yang digambarkan dalam teksteks tersebut mengenai kepemimpinan. Kepemimpinan dalam Islam telah diatur dengan pakem pada teks itu, namun dinamika sejarah dan dialektika ilmu pengetahuan telah menggeser beberapa pakem sesuai dengan konteks masa kini. Tulisan ini hendak mengeksplorasi konsepkonsep ideal kepemimpinan dalam teks tersebut, secara spesifik hadis nabi dan membaca setiap aspek perubahan dalam konteks-konteks tersebut dengan menggunakan kaca mata teori double movement. Tulisan ini merupakan penelitian kualitatif dengan tehnik pengambilan data berupa library research. Dari penelusuran yang telah dilakukan, ada dua konsep kepemimpinan dalam hadis yang dirasa tidak relevan di era kontemporer, konsep tersebut adalah kepemimpinan harus dari kalangan laki-laki dan kepemimpinan harus dari Quraisy.
\end{abstract}

Kata kunci: Konsep Kepemimpinan, Hadis, Gerak Ganda, Kontekstualisasi Konsep.

\begin{abstract}
Leadership is an important entity for human civilization. The existence of an existing community requires a form of leadership that will direct the community to the goals and vision and mission to be achieved. Politics, as a commander who directs the community, is a concrete manifestation of leadership. Islam as a religion that makes the text of the Koran and Hadith and
\end{abstract}


their derivative sciences as a guide, of course, has an ideal conception which is described in these texts regarding leadership. Leadership in Islam has been regulated according to the standard in the text, but the historical dynamics and dialectics of science have shifted several grips according to the present context. This paper intends to explore the ideal concepts of leadership in the text, specifically the hadith of the prophet and read every aspect of change in these contexts using the double movement theory glasses. This paper is a qualitative research with data collection techniques in the form of a research library. From the research that has been carried out, there are two concepts of leadership in the hadith that are deemed irrelevant in the contemporary era, the concept is that leadership must be from men and leadership must be from Quraish.

Keywords: Leadership Concept, Hadith, Double Movement, Conceptualization.

\section{A. Pendahuluan}

Sebagai bagian vital dari kehidupan peradaban, manusia mengharuskan adanya kepemimpinan. Hal tersebut berfungsi untuk mengatur kehidupan agar lebih terarah. Konsep mengenai kepemimpinan secara umum tidak dapat dilepaskan dengan ilmu politik karena konsep tersebut merupakan sub-bagian pembahasan ilmu politik. Politik sendiri, berasal dari bahasa Yunani, polis yang berarti kota (Mufti, 2013). Ketika Yunani masih berada dalam masa negara-kota, setiap penduduk saling bekerja sama dan berinteraksi untuk mencapai kesejahteraan kolektif, dari fenomena inilah kemudian suatu konsepsi mengenai "politik" untuk pertama kali ditulis oleh Plato dalam bukunya "Politeia" yang lebih dikenal sebagai "Republik" (Noer, 1983) dan dari buku tersebut dikembangkan sebuah konsepsi politik oleh Aristoteles dengan bukunya "Politica".

Islam, sebagai bagian dari peradaban juga memiliki kerangka, konsepsi dan aturan mengenai kepemimpinan dan politik. Jika kita telisik kembali ke masa di mana Rasulullah saw hidup, beliau dengan para sahabat telah membentuk suatu bangunan masyarakat dengan tata politik di Madinah. Jika kita menggunakan kaca mata ilmu politik modern untuk menganalisis bangunan masyarakat tersebut, maka dapat dikatakan bahwa tata politik tersebut merupakan tata politik par exxelence (Rais, 2001). Maksud dari par exxelenxe tersebut ialah berbentuk dua arah di mana di satu sisi memiliki tata kelola yang bersifat duniawi dan di sisi lain memiliki 
nilai religiusitas. Hal terakhir dapat kita lihat melalui fundamentalitas dan motif-motif dari bangunan tata politik Islam di era tersebut.

Apa yang telah dibangun oleh Rasulullah saw dengan para sahabat, kemudian menjadi suatu rekaman dalam bentuk hafalan-hafalan yang kemudian di dua abad setelah Rasulullah saw wafat, hafalan tersebut dibukukan (baca: kodifikasi). Hafalan yang kemudian dibukukan inilah yang disebut sebagai "hadis". Di kalangan mayoritas Islam, hadis acapkali didefinisikan sebagai suatu perkataan, perilaku dan persetujuan/ketetapan Rasulullah saw (Rahman F. , 1987), sebagian ulama ada yang menambahi dengan sifat diri atau sifat pribadinya ('Itr, 2014). Ia membentuk suatu teks yang kemudian menjadi norma-norma yang juga par exellence, menjadi hukum-hukum fiqh, akidah dan akhlak serta tashawuf. Wacana politik dan kepemimpinan dalam Islam masuk ke dalam kategori fiqh yang biasa disebut dengan fiqh alsiyasah.

Hadis nabi yang kemudian menjadi bagian sumber hukum dalam wilayah politik Islam, di dalamnya memuat konsep-konsep ideal mengenai pemimpin. Di era kontemporer, konsepkonsep tersebut banyak yang dikompromikan dengan realitas bahkan ada yang menganggapnya sebagai konsep yang tidak relevan, seperti pemimpin harus berasal dari Quraisy. Tulisan ini hendak memaparkan konsep-konsep tersebut dengan menggunakan kaca mata teori hermeneutika double movement Fazlur Rahman dan metode penelitian kualitatif dengan jenis penelitian library research.

\section{B. Landasan Teori}

Permasalahan "cara baca" terhadap teks acapkali menjerumuskan pembaca ke kubangan kekeliruan yang membuatnya menjadi tekstualis dan buta terhadap realitas. Hal tersebut merupakan kegelisahan dari sarjana muslim kontemporer yang kerap melontarkan kritik terhadap cara membaca sebuah teks dengan paradigma atau kerangka berpikir klasik. Salah satu sarjana kontemporer yang melakukan kritik tersebut adalah Fazlur Rahman, ia mengajukan sebuah teori untuk membaca sebuah teks, dalam hal ini Qur'an (dan Hadis) dengan sebuah teori double movement. 
Double movement secara harfiah berarti gerak ganda. Maksud dari gerak ganda tersebut, seperti yang dijelaskan oleh Fazlur Rahman dalam bukunya Islam and Modernity, adalah suatu proses interpretasi yang bertujuan untuk membaca situasi di masa sekarang dengan masa di mana Qur'an turun (masa Rasulullah) (Rahman F. , 1982). Dalam hemat Fazlur Rahman, alQur'an adalah respon ilahi terhadap situasi moral dan sosial bangsa Arab atau secara spesifik terhadap masalah komersial masyarakat Mekkah pada masa kenabian, yang dijelaskan melalui pikiran Nabi Muhammad saw (Rahman F. , 1982). Al-Qur'an yang merupakan pedoman bagi komunitas muslim, tentu memiliki latar belakang sosio-historis, teks-teks di dalamnya terkadang menjawab sebuah pertanyaan atau suatu masalah, namun seringkali jawaban tersebut dinyatakan di dalam term-term yang secara eksplisit maupun semi eksplisit bersifat "ratio legis”. Sementara di dalamnya juga dinyatakan hukum-hukum tertentu dari waktu ke waktu. (Rahman F. , 1982).

Untuk menerapkan double movement sebagai sebuah cara untuk memahami al-Qur'an dan hadis, ada dua gerak langkah yang telah ditetapkan. Gerak langkah pertama adalah bergerak dari situasi sekarang menuju ke masa al-Qur'an (Rasulullah). Rahman, memberikan sublangkah dalam gerak langkah pertama. Sub-langkah tersebut, pertama adalah memahami alQur'an secara menyeluruh di samping masih dalam batas-batas ajaran khusus dan merupakan respon atas situasi khusus, kedua melakukan generalisasi atas makna-makna yang khusus tersebut dan menyatakan sebagai “makna” berupa pernyataan yang bertujuan menjawab moralsosial secara umum yang tersaring dari teks-teks spesifik berlatar belakang sosio-historis dan ratio legis. Pembacaan atas latar belakang sosio-historis dinamai oleh Rahman sebagai "IdealMoral". Ideal-moral tersebut adalah nilai-nilai universal yang berada dalam teks al-Qur'an (dan hadis). Tujuan moral tersebut berlaku sepanjang masa. Dari nilai universal yang telah tertulis itu, munculah gerak langkah kedua.

Gerak langkah kedua yang diajukan Rahman untuk membaca suatu teks, adalah mengkhususkan kembali "pandangan umum" yang dirumuskan dan direalisasikan pada masa sekarang. Nilai-nilai moral yang telah diperoleh dari gerak pertama yang telah disusun sebagai “ideal-moral" kemudian diaplikasikan di masa kini. Langkah kedua ini adalah olahan lebih lanjut dari gerak langkah pertama untuk kemudian menjadi kesimpulan dari proses membaca dan memahami sebuah teks. 
C. Konsep Kepemimpinan dalam Hadis (“Ideal-Moral”)

Nabi Muhammad saw merupakan sosok sempurna dalam kehidupan. Segala hal yang berkaitan dengannya merupakan sesuatu yang memiliki nilai kemuliaan. Begitu pula dalam persoalan kepemimpinan dan politik. Beberapa konsep yang terekam dalam hadis-hadis mengenai kepemimpinan yang ideal dapat dilihat sebagai berikut:

1. Urgensi kepemimpinan

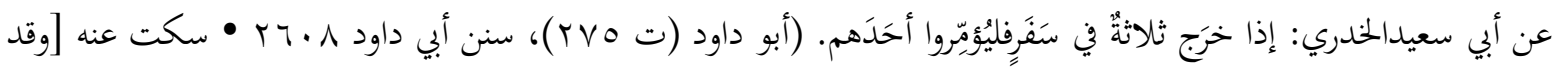

$$
\begin{aligned}
& \text { قال في رسالته لأهل مكة كل ما سكت عنه فهو صالح] • أخرجه أبو داود (1 • بr)، والطبراني في 》المعجم الأوسط《) } \\
& \text { (ب . (1)، والبيهقي (101 • 1) [لفظه نفس لفظ الحديث ا مع اختلاف في الحركات أو علامات الترقيم]) }
\end{aligned}
$$

"Dari Abu Sa'id al-Khudri r.a: Jika tiga orang keluar dalam sebuah perjalanan, maka perintahkanlah salah satu orang dari mereka untuk menjadi pemimpin" (HR. Imam Abu Dawud no. 2608, Imam Thabrani no. 8093, Imam Baihaqi no. 10651 ).

Pada hadis di atas, Rasulullah saw memerintahkan agar menunjuk satu pemimpin dalam satu kelompok yang melakukan safar. Hal tersebut secara eksplisit menunjukkan akan pentingnya sebuah kepemimpinan untuk mengarahkan sekelompok manusia kepada tujuan yang ingin dicapai.

2. Pemimpin harus ditaati

$$
\begin{aligned}
& \text { عن عبدالله بن عمر: على المريٌ المسلمِ السمعُ و الطاعةُ، فيما أحبَّ و كَرِة، إلا أن يُؤْمَرَ بمعصيةٍ، فإذا أُمِرَ بمعصيةٍ، فلا سمعَ و لا }
\end{aligned}
$$

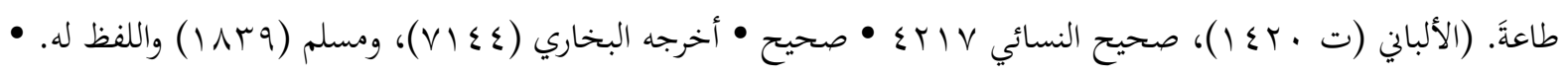

$$
\begin{aligned}
& \text { شرح رواية أخرى) }
\end{aligned}
$$

"Dari 'Abdullah ibn Umar: terhadap pemimpin muslim, dengar dan taatlah (kalian)!, baik dalam keadaan suka atau benci, kecuali jika (pemimpin itu) menyuruh kepada kemaksiatan, 
maka jika (pemimpin itu) menyeru kepada kemaksiatan, janganlah (kalian) mendengar dan menaatinya! (HR Imam Nasa'i no. 4217, Bukhari no. 7144, Imam Muslim 1839).

Hadis tersebut menyeru kepada umat Islam agar mendengar dan menaati pemimpinnya dengan pengecualian jika pemimpin tersebut menyeru mereka kepada kemaksiatan.

3. Pemimpin Hanya Boleh ada satu

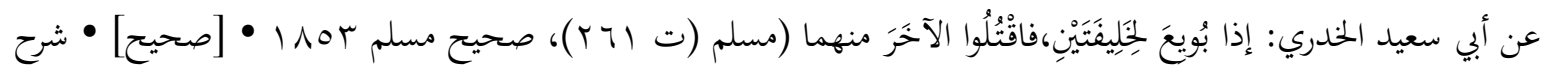

$$
\begin{aligned}
& \text { الحديث [لفظه نفس لفظ الحديث r مع اختلاف في الحركات أو علامات الترقيم]) }
\end{aligned}
$$

"Dari Abu Sa'id al-Khudri r.a: Jika diangkat (dari kalian) dua Khalifah, maka bunuhlah salah satu dari mereka" (HR Imam Muslim no. 1853).

Kata "bunuh" dalam hadis tersebut menunjukkan bahwa seorang pemimpin umat hanya boleh ada satu. Hal tersebut dikarenakan jika dalam satu ruang dan waktu ada dua pemimpin, maka akan terjadi kekacauan, baik itu disebabkan silang kebijakan atau berpotensi memecah belah umat.

4. Pemimpin Harus ditunjuk oleh Rakyat dan Makruh berhasrat untuk memimpin.

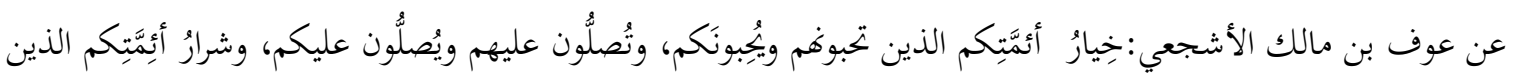

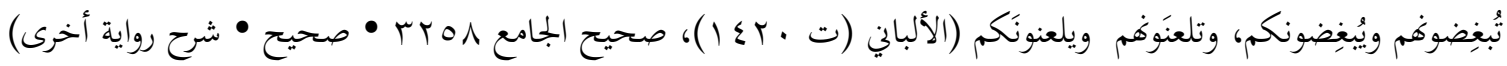

"Dari 'Auf Ibn Malik al-Asyja'i: Sebaik-baik pemimpin (dari kalian) adalah yang kalian mencintai mereka, dan mereka(pun) mencintai kalian, dan kalian mendoakan mereka, mereka(pun) mendoakan kalian, sedangkan seburuk-buruk pemimpin dari kalian adalah yang kalian marah (benci) terhadap mereka dan mereka(pun) marah (benci) terhadap kalian, kalian melaknat mereka dan mereka (juga) melaknat kalian (HR Bukhari (al-Jami') no.3258).

Hadis di atas mengindikasikan akan pentingnya sosok pemimpin yang dicintai rakyat dan oleh karena itu, maka ia juga merupakan hasil dari pemilihan rakyat. Pemimpin yang baik adalah yang dicintai dan didoakan oleh rakyat dan sang pemimpinpun mencintai dan 
mendoakan rakyat, sementara pemimpin yang buruk adalah mereka yang berada dalam posisi vis a vis dengan rakyat, mereka dibenci dan dilaknat oleh rakyat, begitu pula sebaliknya, mereka mengutuk dan membenci rakyat.

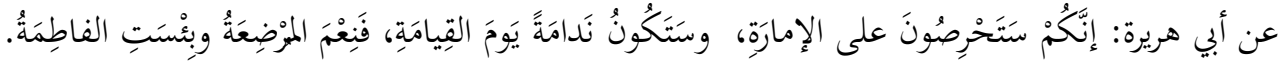

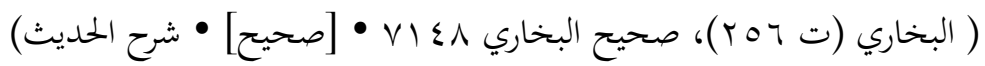

"Dari Abu Hurairah: Sesungguhnya kalian akan menginginkan kekuasaan, suatu perkara yang akan kalian sesali di hari kebangkitan, betapa lezatnya perempuan yang menyusu dan alangkah celaka perempuan yang menyapih" (HR Imam al-Bukhari no. 7148).

Hadis tersebut memiliki kandungan makna bahwa seseorang di antara suatu kelompok dihimbau agar tidak mendaulat diri sebagai pemimpin dan berharap agar segala perkataannya didengar dan ditaati. Seperti yang telah dijelaskan sebelumnya bahwa seorang pemimpin sejatinya harus lahir dari rahim rakyat.

5. Pemimpin harus laki-laki

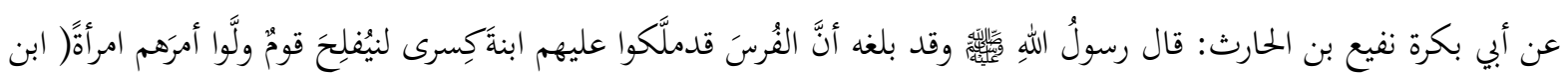

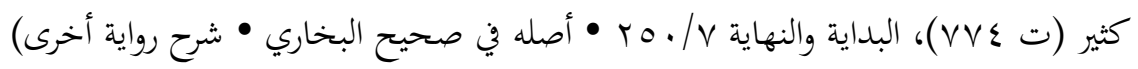

"Dari Abu Bakrah Nafi' ibn Harits, Rasulullah saw bersabda: "dan (Rasulullah) telah (mengetahui sebuah) berita sesungguhnya Persia memiliki seorang puteri Kisra, orang yang menyerahkan (kepemimpinan) terhadap wanita tidak akan berhasil”' (HR Imam Bukhari)

Hadis mengenai tidak bolehnya perempuan memimpin memiliki latar belakang historis tentang kerajaan Kisra yang akan dipimpin oleh seorang puteri. Dalam hadis tersebut Rasulullah saw memberi tanda bahwa ratu tersebut akan gagal dalam memimpin rakyatnya.

6. Pemimpin harus dari kaum Quraisy

$$
\text { عن معاوية بن أبي سفيان: إِنَّ هذا الأمَرَ في قريُشِ، لا يعاديهم أحدٌ إلّا كَبَّهُ اللهُ على وجْهِهِ؛ ما أقاموا الدِّينَ (الألباني (ت }
$$




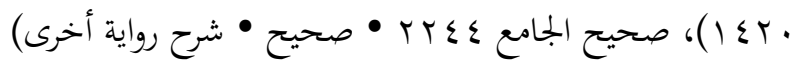

"Dari Mu'awiyah Ibn Abu Sufyan: Sesungguhnya perkara (kepemimpinan) ini ada pada Quraisy, tidak ada yang akan menentang mereka kecuali Allah swt akan menindas (/melemparkan) wajah mereka (ke dalam neraka) selama mereka berpegang teguh terhadap agama (HR Bukhari (al-Jami') no. 2244).

Hadis di atas menunjukkan bahwa segala bentuk kepemimpinan mengharuskan agar berada di tangan kaum Quraisy dan setiap kaum Muslim yang menentang hal tersebut akan masuk neraka.

Dari beberapa hadis yang telah dipaparkan, maka dapat dianalisis beberapa poin spesifik yang merupakan konsep-konsep kepemimpinan di dalam hadis Nabi saw. adapun poin-poin tersebut ialah (1) kepemimpinan merupakan sebuah keharusan, (2) taat kepada pemimpin merupakan kewajiban dengan pengecualian jika sang pemimpin memerintahkan untuk melakukan maksiat, (3) pemimpin hanya boleh ada satu karena jika lebih dari itu, potensi perpecahan dan silang kebijakan sangat besar, (4) pemimpin harus ditunjuk oleh rakyat,(5) mendaulat diri sebagai pemimpin merupakan suatu hal yang tidak etis, (6) pemimpin harus dari kalangan laki-laki, dan (7) kepemimpinan harus dipegang oleh suku Quraisy. Selaras dengan petunjuk-petunjuk yang khusus tersebut, maka harus ditarik sebuah benang merah generalisasi yang akan menjadi pisau analisis untuk menerapkan langkah kedua dalam teori double movement.

Konsep-konsep dalam hadis yang telah dijabarkan sedemikian rupa di atas, tidak lahir dalam ruang yang "hampa sosio-historis". Pada era nabi, hadis-hadis tersebut muncul dalam konteks tata kelola politik di Madinah. Muhammad Arkoun, seperti yang dijelaskan oleh Nurcholish Madjid,membuat istilah pembangunan tata politik di Madinah pada era Nabi sebagai “eksperimen Madinah" (Nurcholis Madjid, 2017). Eksperimen Madinah tersebut telah memberikan pelajaran kepada seluruh manusia tentang tatanan sosial-politik yang mengenal pendelegasian wewenang, dalam arti wewenang atau kekuasaan tidaklah terpusat dalam satu genggaman orang seperti dapat kita lihat dalam sistem diktator. Eksperimen Madinah mengajarkan bahwa kekuasaan diserahkan kepada orang banyak melalui jalan musyawarah dan 
kehidupan berkonstitusi (Nurcholis Madjid, 2017). Wujud historis dari eksperimen Madinah adalah Piagam Madinah (Mitsaq al-Madinah) yang telah terdokumentasi dan menjadi bukti bahwa tatanan sosial-politik pada masa Rasulullah saw menekankan konstitusi, yakni dokumen tertulis yang disepakati bersama sebagai nomor satu. Lebih lanjut, Al-Sayid Muhammad Ma'ruf al-Dawalibi berkomentar terkait Mitsaq al-Madinah “yang paling menakjubkan dari segala hal mengenai Konstitusi Madinah adalah bahwa dokumen tersebut memuat prinsip dan kaedah kenegaraan dan nilai-nilai kemanusiaan untuk pertama kalinya di mana umat manusia sebelum itu belum mengenalnya" (Nurcholis Madjid, 2017). Hal tersebut menunjukkan bahwa Rasulullah saw, selain bertugas sebagai manusia suci yang membawa risalah, juga merupakan sosok yang fathonah dan revolusioner yang mampu menyatukan perbedaan, mengingat banyak kaum di Madinah kala itu seperti Arab Muslim dari Makkah dan Madinah, Suku Khazraj, Suku 'Aus yang muslim, kaum Yahudi serta kaum paganis. (Pancaningrum, 2018)

Persoalan "nilai kemanusiaan dan ketata-negaraan" merupakan dua aspek penting yang menjadi kunci dalam memahami hadis-hadis di atas secara kontekstual. Hal tersebut merupakan nilai universalitas yang dapat diasumsikan berlaku sepanjang zaman. Dengan kata lain dua aspek tersebut merupakan raison d'etre bagi kepemimpinan dan tata sosial-politik di dalam Islam. Hal tersebut juga memiliki keselarasan dengan maqashid syar'iyah yang di dalamnya memuat lima aspek penting dari diselenggarakannya syariat Islam. Lima aspek tersebut adalah hifdhu al-din (menjaga agama), hifdhu al-nafs (menjaga jiwa), hifdhu al- 'aql (menjaga akal), hifdhu al-nasl (menjaga keturunan) dan hifdhu al-maal (menjaga harta benda) yang eksis dalam kerangka kemanusiaan dan ketata-negaraan (sosial politik) (Amalia, 2017).

D. Kontekstualisasi Konsep Kepemimpinan dalam Hadis

Pada era kontemporer, persoalan agama dan politik telah menjadi suatu pembahasan yang menjadi arus utama dalam beberapa dekade terakhir, khususnya setelah kejadian 11 September 2001 (Library of Congress Cataloging in Publication Data, 2011). Permasalahan tersebut telah menyeret Islam ke dalam pusaran peradaban (post-)modern secara kasar. Dari fenomena tersebut munculah dua permasalahan di dalam Islam. Permasalahan tersebut adalah problem eksternal dan problem internal. Di dalam problem eksternal, Islam harus berhadap-hadapan 
dengan peradaban "Barat" yang kemudian menjadi ketegangan dan menimbulkan tindakantindakan yang seolah tak mengindahkan nilai kemanusiaan dan nyaris dapat disebut sebagai barbarisme. Persoalan islamophobia kemudian merebak dan membuat Islam dihujat habishabisan oleh Barat. Sementara pada problem internal, muncul pertanyaan-pertanyaan dan diskursus mengenai relevansi gagasan Islam. Hal terakhir kemudian menempatkan umat Muslim dalam dua lorong pilihan, mengikuti pergerakan zaman atau kembali ke zaman di mana Islam muncul. Pilihan-pilihan ini tentu juga bersinggungan dengan masalah kepemimpinan dan politik yang kemudian banyak diperdebatkan.

Seperti yang telah disinggung sebelumnya, Islam pada era kenabian,memiliki konsep besar kepemimpinan dan tatanan sosial-politik yang mengindahkan kemanusiaan dan kesepakatan kolektif. Namun, disadari atau tidak, nilai-nilai tersebut tentu telah bergeser seiring dengan perkembangan zaman yang, hampir dikatakan, mustahil untuk dibendung. Dari konsep-konsep hadis yang telah diuraikan sebelumnya, ada dua konsep yang dianggap irelevan mengenai kepemimpinan. Dua konsep tersebut adalah "pemimpin harus dari kalangan laki-laki" dan "pemimpin harus dari suku Quraisy".

Wacana keadilan gender yang telah mengemuka dalam beberapa tahun terakhir, telah membuat Islam juga ikut ambil bagian di dalamnya. Nasr Hamid Abu Zayd, dalam bukunya dekonstruksi gender menjelaskan bahwa permasalahan perempuan di sepanjang peradaban Arab-Islam bukan hanya terletak pada problem jenis kelamin, perempuan dan laki-laki, bukan hanya membahas masalah kemunduran sosial atau kemunduran berfikir, masalah yang dibahas juga bukan hanya problem keagamaan, namun yang menjadi titik pangkal permasalahan adalah problem "krisis otoritas politik" yang mencakup semua yang telah dibahas di atas dalam hubungannya dengan manusia sejak permulaan sejarah Arab (Zayd, 2003). Wacana mengenai perempuan yang diproduksi (dan direproduksi) di dunia Arab hari ini secara global, adalah wacana yang memiliki sifat sektarian-rasialistik, dengan arti bahwa hal itu membicarakan keabsolut-an perempuan dan memberikannya tempat dalam hubungan-komparatif dengan keabsolut-an laki-laki. Laki-laki selalu menempatkan diri sebagai superior-sentralistik, tak ada kesetaraan yang hakiki, jika hal tersebut ada maka artinya berada dalam wilayah otoritas dengan parameter-parameter yang dibangun oleh laki-laki, jika ada kerja sama antara laki-laki dan perempuan, maka hal tersebut bermakna "bakti" perempuan terhadap laki-laki. Hal ini 
sejatinya bukan hanya dalam wilayah keagamaan, namun Arab secara umum (Zayd, 2003). Dari kritik yang cukup tajam tersebut dapat dipahami bahwa wacana keadilan gender dewasa ini menjadi persoalan yang cukup signifikan dan cukup mumpuni untuk mendelegitimasi persyaratan ideal seorang pemimpin harus dari laki-laki. Jika hadis di atas dibaca kembali secara teliti, maka dapat dipahami bahwa Rasulullah saw hanya berkomentar tentang kekuasaan Kisra pada masa itu. Konteks itu sejatinya sudah clear untuk menjawab kebolehan perempuan sebagai pemimpin. Selain itu, cerita mengenai 'Aisyah yang menjadi "komandan militer" di dalam perang Jamal juga bisa di-qiyas-kan dalam permasalahan ini. Dalam kaitannya dengan al-Qur'an masalah قو ام dalam surah an-Nisa ayat 34 juga ditafsirkan dengan penafsiran yang lebih egaliter dengan tidak mengatakan bahwa semua laki-laki memiliki kelebihan terhadap perempuan, namun hanya beberapa saja dan bukan merupakan suatu yang alamiah (Saeed, 2016).

Sebagai sebuah risalah yang sempurna, Islam telah membentuk suatu masyarakat yang punya partisipasi yang cukup tinggi dalam ranah politik. Hal tersebut senada dengan pendapat Robert. N. Bellah yang dikutip oleh Nurcholis Madjid, bahwa masyarakat Islam klasik itu modern secara mencolok (remarkably modern). Namun pujian tersebut hanya disematkan kepada masyarakat Islam yang eksis dari era nabi hingga era Khulafa al-Rasyidun. Setelah para khalifah wafat, Islam menemui jurang kekabilahan-nya kembali pada masa Bani Umayah. Sistem kekabilahan (tribal) telah menggantikan sistem yang modern tersebut, dan ini adalah suatu kegagalan. Kegagalan tersebut terjadi karena belum adanya infrastruksur sosial untuk menyangganya. (Madjid, 2008)

Adapun poin yang menjadikan Bellah menilai masyarakat Islam klasik sebagai modern adalah partisipasi politik yang terbuka dari seluruh jajaran anggota masyarakat. Poin lainnya adalah keterbukaan dan kemungkinan posisi pimpinan masyarakat untuk diuji secara kualitatif. Hal tersebut disimbolkan dengan penunjukkan pemimpin melalui jalan pemilihan dan bukan warisan atau keturunan (Madjid, 2008). Konteks ini adalah poin penting untuk menimbang apakah relevan jika pemimpin ideal "harus" dari Quraisy (?) konteks yang lebih dekat dengan kita adalah kebudayaan yang nota bene memiliki perbedaan yang terlampau jauh dengan Arab dan khususnya Quraisy, begitu pula dengan Persia, Asia Timur, Eropa dan lain sebagainya. 
E. Kesimpulan

Kepemimpinan merupakan hal yang pokok dalam kehidupan bermasyarakat. Wacana mengenai kepemimpinan beserta seperangkat konsep, teori dan praktiknya tidak bisa dilepaskan dari wacana politik. Islam sebagai agama yang eksis di peradaban manusia, tentunya memiliki konsepsi ideal tersendiri mengenai kepemimpinan. Dengan pembacaan dari teks-teks hadis melalui kaca mata teori double movement Fazlur Rahman, ditemukan beberapa konsep khusus tentang kepemimpinan, antara lain: (1) kepemimpinan merupakan sebuah keharusan, (2) taat kepada pemimpin adalah kewajiban, kecuali jika diperintah untuk mengerjakan hal munkar/maksiat, (3) pemimpin hanya boleh ada satu, (4) pemimpin harus ditunjuk/dipilih oleh rakyat, (5) makruh mendaulat diri sebagai pemimpin, (6) pemimpin harus dari kalangan laki-laki dan (7) pemimpin harus dari suku Quraisy. Konteks dari keseluruhan hadis tersebut muncul dari tata kelola sosio-politik di Madinah yang menegaskan adanya nilainilai kemanusiaan dan konstitusi. Dari dua nilai tersebut dapat ditarik suatu benang merah yang kemudian merubah beberapa makna ideal-moral hadis. Dua poin yang dianggap irelevan adalah pemimpin harus dari kalangan laki-laki dan pemimpin harus dari suku Quraisy. Wacana kesetaraan gender dan prinsip egalitarian tanpa memandang kesukuan di era kontemporer telah mendelegitimasi dua poin ideal mengenai kepemimpinan tersebut. 


\section{Daftar Pustaka}

Amalia, N. R. (2017). Penerapan Konsep Maqashid Syariah untuk Realisasi Identitas Politik Islam di Indonesia. Dauliyah, 31-49.

'Itr, N. (2014). 'Ulumul Hadis. Bandung: PT Remaja Rosdakarya.

Library of Congress Cataloging in Publication Data. (2011). 21st Century Political Science: A Reference Handbook. California: Sage Publications.

Madjid, N. (2008). Islam, Doktrin dan Peradaban. Jakarta: PT Dian Rakyat.

Mufti, M. (2013). Teori-Teori Politik. Bandung: Pustaka Setia.

Noer, D. (1983). Pengantar ke Pemikiran Politik . Jakarta: Rajawali.

Nurcholis Madjid, d. (2017). Islam Universal. Yogyakarta: Pustaka Pelajar.

Pancaningrum, N. (2018). Kontekstual Konsep Pemimpin dalam Teks Hadis. Riwayah : Jurnal Studi Hadis, 204-224.

Rahman, F. (1982). Islam and Modernity: Transformation of an Intellectual Tradition. Chicago: The University of Chicago Press.

Rahman, F. (1987). Ikhtishar Musthalahul Hadits. Bandung: PT Alma'arif.

Rais, M. D. (2001). Teori Politik Islam. Jakarta: Gema Insani Press.

Saeed, A. (2016). Al-Qur'an Abad 21: Tafsir Kontekstual. Bandung: Mizan.

Zayd, N. H. (2003). Dekonstruksi Gender. Yogyakarta: Samha. 